\title{
PENGARUH PENDAMPINGAN KADER TERHADAP PEMBERIAN ASI EKSKLUSIF DI WILAYAH KERJA PUSKESMAS CIKULUR KABUPATEN LEBAK
}

\author{
THE IMPACT OF CADRE ACCOMPANIMENT TOWARDS EXCLUSIVE \\ BREASTFEEDING IN THE WORKING AREA OF CIKULUR \\ PUBLIC HEALTH CENTER LEBAK DISTRICT
}

\author{
Omo Sutomo \\ Politeknik Kesehatan Kemenkes Banten \\ Korespondensi: gunungkarang19@gmail.com
}

\begin{abstract}
Exclusive breastfeeding has a huge contribution towards children's growth and immunity (Patal, 2013). Unfortunately, not every mother succeeds in breastfeeding especially the first six months of the baby's birth. According to Data and Information Center of Ministry of Health of Indonesian Republic (2014), the scope of exclusive breastfeeding nationally was still low (54.3\%), so was in Banten Province it was considered low (47.9\%). This reasearch aimed to figure out the impact of cadre accompaniment towards exclusive breastfeeding in Cikulur Public Health Center working area, Lebak District in 2018. This research is a quasi experimental research, multiple times series design. The samples were 92 puerperial mothers (46 as experimental, 46 as control samples). Those samples were picked with quata sampling technique. To find out the impactr mean, $0.05 \alpha$ value was used. The research results showed that more than a half numbers of the mothers did not breastfeed (51.1\%). The number of mothers who did not breastfeed was bigger (63.0\%), that happened to those who were not accompanied by cadre compared to those who had cadre accompaniment there was only $39.1 \%$ of them who did not do the breastfeeding to their babies. There was a significant impact of cadre accompaniment towards exclusive breastfeeding $(p=0,037)$. Mothers who were not accompanied by cadre had more risks of not doing the breastfeeding three times than those who had cadre accompaniment $(O R=2,654)$.
\end{abstract}

Key words: Cadre Accompaniment, Exclusive Breastfeeding.

\begin{abstract}
ABSTRAK
Pemberia ASI eksklusif memiliki kontribusi yang besar terhadap tumbuh kembang dan daya tahan tubuh anak (Patal, 2013), Sayangnya tidak semua ibu berhasil dalam menyusui terutama dalam enam bulan pertama kehidupan bayi. Menurut Pusat Data dan Informasi Kemenkes RI (2014), cakupan ASI eksklusif secara Nasional masih rendah (54,3\%), demikian pula di provinsi Banten masih tergolong rendah (47,9\%). Penelitian ini bertujuan untuk mengetahui pengaruh pendampingan kader terhadap pemberian ASI eksklusif di wilayah kerja Puskesmas Cikulur Kabupaten Lebah tahun 2018. Penelitian ini merupakan penelitian quasi eksperiment,
\end{abstract}


rancangan seri ganda (multiple time series) design). Sampel ialah ibu pasca nifas sebanyak 92 orang ( 46 orang perlakuan dan 46 orang kontrol). Sampel diambil dengan teknik quata sampling. Untuk mengetahui kemaknaan pengaruh digunakan nilai $\alpha$ sebesar 0,05 . Hasil penelitian menunjukkan bahwa lebih dari separuhnya ibu tidak memberikan ASI eksklusi (51,1\%). Ibu yang tidak memberikan ASI eksklusif lebih banyak (63.0\%) terjadi pada ibuyang tidak didampingi oleh kader dibandingkan dengan ibu yang didampingi kader hanya 39,1\% yang tidak memberikan ASI eksklusif pada bayinya. Terdapat pengaruh yang signifikan pendampingan kader terhadap pemberian ASI eksklusif $(\mathrm{p}=0,037)$. Ibu yang tidak mendapat pendampingan kader berisiko hampir tiga kali lebih besar untuk tidak memberikan ASI eksklusif pada bayinya dibandingkan dengan ibu yang mendapat pendampingan kader $(\mathrm{OR}=2,654)$

\section{Kata Kunci: Pendampingan Kader, Pemberian ASI Eksklusif.}

\section{PENDAHULUAN}

ASI eksklusif diartikan bahwa bayi sampai enam bulan hanya diberikan ASI saja (dikecualikan obat-obatan, mineral dan cairan mineral tetes). Patal (2013) menjelaskan bahwa ASI eksklusif memiliki kontribusi yang besar terhadap tumbuh kembang dan daya tahan tubuh anak. Menyusui secara eksklusif dapat menurunkan angka kematian karena infeksi (88 $\%)$ pada bayi berusia kurang dari 3 bulan, investasi dalam pencegahan BBLR, stunting dan meningkatkan IMD. ASI eksklusif berkontribusi dalam menurunkan risiko obesitas dan penyakit kronis.

Adiningrum (2014), menjelaskan bahwa menyusui menyusui merupakan sebuah tindakan yang efektif. Selain lebih ekonomis, menyusui juga lebih praktis dan mengurangi risiko yang akan memberi efek yang tidak murah penangannya. Dengan memberi ASI, keluarga tidak perlu menambah beban untuk membeli susu formula yang mahal dan berisiko mengandung bakteri, sehingga alokasi biaya rumah sakit akibat asupan yang salah dapat ditekan. Sayangnya tidak semua ibu berhasil dalam menyusui terutama enam bulan pertama kehidupan bayi. Kondisi ini memberi dampak pada capaian target cakupan pemberian ASI eksklusif yang telah dicanangkan oleh pemerintah bahwa $100 \%$ bayi harus diberikan ASI eksklusif masih menjadi harapan.

Secara Nasional Pusat Data dan Informasi (2014) menyebutkan bahwa cakupan ASI eksklusif masih rendah (54,3\%), Di provinsi Banten cakupan ASI eksklusif masih rendah, yakni dibawah cakupan secara nasional yaitu sebesar 47,9\%. Demikian pula hasil studi pendahuluan di Puskesmas Cikulur Kabupaten Lebak pada bulan Januari 2018, pemberian ASI eksklusif dalam kurun waktu tiga tahun menunjukkan pemberian ASI eksklusif masih rendah, yakni tahun 2015 (25\%), tahun 2016 (30\%), dan tahun 2017 (36\%). 
Berbagai upaya telah dan terus dilakukan oleh Pemerintah dalam hal ini Kementerian Kesehatan, namun belum menunjukkan hasil yang menggembirakan. Kondisi ini tentu sangat memprihatinkan yang jika tidak mendapat perhatian dan penanganan dengan baik, tentu akan memberi implikasi terhadap status kesehatan khususnya kesehatan bayi dan balita serta rendahnya daya saling masayarakat. Karena itu perlu dicari upaya yang lebih efektif melalui pemberdayaan masyarakat dengan melibatkan peran kader kesehatan dalam kegiatan pendampingan pada ibu yang memiliki bayi dalam masa menyusui secara eksklusif yaitu pada usia enam bulan tahun pertama kehidupan bayi. Pendampingan pada hakekatnya adalah bantuan dari pihak luar, baik perorangan maupun kelompok untuk menambah kesadaran dalam rangka pemenuhan kebutuhan dan permasalahan.

\section{METODE}

Penelitian ini merupakan penelitian Quasi eksperiment, dengan rancangan eksperimen seri ganda (multiple time series design). Populasi ialah seluruh ibu nifas di wilayah kerja Puskesmas Cikulur Kabupaten Lebak, dengan jumlah sampel sebanyak 92 orang (46 orang kelompok perlakuan dan 46 orang kelompok kontrol). Sampel diambil dengan teknik quota sampling. Variabel independen penelitian ini ialah pendampingan kader dan variabel dependen ialah pemberian ASI eksklusif. Penelitian ini dilakukan di wilayah kerja Puskesmas Cikulur Kabupaten Lebak pada tahun 2018. Untuk mendapatkan data sesuai tujuan penelitian, sampel dibagi dua kelompok (perlakuan dan kontrol). Pendampingan dilakukan kader terhadap ibu setelah selesai dilakukan kunjungan nifas ke 3 (42 hari) dan masih menyusui banyinya secara eksklusif. Pada kelompok perlakuan dilakukan wawancara sekaligus pendampingan melalui kegiatan diskusi tentang ASI eksklusif dan motivasi sebagai penguat bagi ibu untuk memberikan ASI eksklusif. Sementara pada kelompok kontrol hanya dilakukan wawancara/ ditanyakan tentang keberlangsungan pemberian ASI eksklusif. Untuk menghindari diskriminasi, maka pada kelompok kontrol pada akhir kunjungan dilakukan diskusi dan motivasi terkait dengan ASI eksklusif. Pendampingan dilakukan sebanyak tujuh kali, yakni pendampingan kesatu ke pendampingan kedua dengan interval dua minggu. Pendampingan kedua ke pendampingan ketiga dengan interval tiga minggu, selanjutnya pendampingan ketida sampai ketujuh dengan interval empat minggu. Pelaksanaan penelitian melibatkan petugas Puskesmas Cikulur, bidan di desa dan kader Posyandu.

Analisis data dilakukan secara bertahap, yakni analisis univariat kemudian bivariat. Uji 
statistik digunakan uji Chi Square, dengan nilai

$\mathrm{OR}=2,654(1,143-6,159)$ alpa $(\alpha) 0.05$.

\section{HASIL}

1. Pemberian ASI Eksaklusif

Pemberian ASI eksklusif pada bayi di wilayah kerja Puskesmas Cikulur disajikan pada tabel 1 berikut :

Tabel 1

Distribusi Ibu Menyusui Menurut Pemberian ASI Eksklusif

\begin{tabular}{|c|c|c|}
\hline Pemberian ASI & $\mathrm{f}$ & $\%$ \\
\hline \multicolumn{3}{|l|}{ Eksklusif } \\
\hline - Tidak diberikan & 47 & 51,1 \\
\hline - Diberikan & 45 & 48,9 \\
\hline Total & 92 & 100,0 \\
\hline
\end{tabular}

Berdasarkan tabel 1 diatas menunjukkan bahwa lebih dari separuhnya $(51,1 \%)$, ibu tidak memberikan memberikan ASI eksklusif secara penuh pada bayinya.

2. Pendampingan Kader Posyandu dan Pemberian ASI Eksklusif

Tabel 2

Distribusi Ibu Menyusui Berdasarkan

Pendampingan Kader Posyandu dan Pemberian ASI Eksklusif

\begin{tabular}{lcccc}
\hline $\begin{array}{c}\text { Pendam } \\
\text { pingan } \\
\text { Kader } \\
\text { Posyandu }\end{array}$ & \multicolumn{2}{l}{ Pemberian ASI Eksklusif } & Jumlah & Nilai p \\
\cline { 2 - 3 } & Didakerikan & Diberikan & & \\
\hline Tidak & 29 & 17 & 46 & \\
Didampingi & $(63,0 \%)$ & $(37,0 \%)$ & $(100,0 \%)$ & 0,037 \\
\cline { 1 - 2 } Didampingi & 18 & 28 & 46 & \\
& $(39,1 \%)$ & $(60,9 \%)$ & $(100,0 \%)$ & \\
\hline Total & 47 & 45 & 92 \\
& $(51,1 \%)$ & $(48,9 \%)$ & $(100,0 \%)$ & \\
\hline
\end{tabular}

Tabel 2 di atas menunjukkan bahwa ibu yang tidak memberikan ASI eksklusif lebih banyak $(63,0 \%)$ terjadi pada ibu yang tidak didampingi oleh kader, dibandingkan dengan ibu yang didampingi kader hanya 39,1 \% yang tidak memberikan ASI eksklusif pada bayinya.

Hasil uji statistik diperoleh nilai $p=0,037(p<\alpha)$, berarti terdapat pengaruh yang signifikan pendampingan kader terhadap keberlangsungan pemberian ASI eksklusif. Nilai OR diperoleh sebesar 2,654, artinya ibu yag tidak mendapat pendampingan oleh kader berisiko hampir tiga kali lebih besar untuk tidak memberikan ASI eksklusif pada bayinya dibandingkan dengan ibu yang mendapat pendampingan kader.

\section{PEMBAHASAN}

Secara deskripsi hasil penelitian ini menunjukkan lebih dari separuhnya ibu tidak memberikan ASI eksklusif pada bayinya, kondisi ini tentu memprihatinkan yang jika dibiarkan akan mempengaruhi tumbuh kembang bayi. Bayi yang tidak mendapat ASI eksklusif akan kehilangan banyak dari manfaat dari bayi yang mendapat ASI, karenanya disarankan untuk menyusui bayi secara eksklusif selama enam bulan dan tetap melanjutkan menyusui sampai usia anak dua tahun. Menurut Adiningrum (2014), bayi yang diberi ASI akan lebih sehat dibandingkan dengan bayi yang tidak mendapat ASI (diberi 
susu formula). Bayi yang mendapat atau diberikan ASI akan membantu mengoptimalkan perkembangan sistem saraf serta perkembangan otak bayi. Kandungan ASI luar biasa dan tidak terdapat pada jenis susu manapun. Sebaliknya jika bayi mendapatkan susu formula maka bayi bisa mengalami diare, sakit perut, alergi makanan, asma, diabetes, dan penyakit saluran pencernaan kronis.

Keberadaan kader di posyandu saat ini masih diperlukan mengingat kedekatan mereka dengan sasaran yakni ibu hamil, ibu menyusui maupun pasangan usia subur, melalui merakalah kegiatan posyandu digerakan bersama petugas kesehatan (bidan). Pemanfaatkan keberadaan karena kedekatan dengan masyarakat dapat dijadikan sebagai sarana untuk mendorong capaian program kesehatan. Salah satunya dengan mendorong kader posyandu sebagai pendamping dalam keberhasilan pemberian ASI eksklusif, mengingat cakupan saat ini masih rendah.

Hasil penelitian secara bivariat menunjukkan bahwa terdapat pengaruh yang signifikan pendampingan kader posyandu terhadap pemberian ASI eksklusif. Ibu yag tidak mendapat pendampingan oleh kader posyandu berisiko hampir tiga kali lebih besar untuk tidak memberikan ASI eksklusif pada bayinya dibandingkan dengan ibu yang mendapat pendampingan kader posyandu.
Jadi jelas betapa pentinya peran pendamping atau kader posyandu dalam keberlangsungan pemberian ASI eksklusif. Peran yang dapat dilakukan oleh kader posyandu dalam rangka pendampingan adalah berperan sebagai (1) motivator artinya kader melakukan upaya penyadaran dan mendorong agar individu/ibu yang memiliki bayi untuk mengenal potensi dan masalah, dan dapat mengembangkan potensinya untuk memecahkan permasalahan tersebut, (2) fasilitator artinya kader mempunyai tanggung jawab untuk menciptakan, mengkondisikan iklim kelompokyang harmonis serta manfasilitasi terjadinya saling belajar dalam kelompok, dan (3) katalisator, kader berperan sebagai penghubung antara kelompok pendamping dengan lembaga di luar kelompok maupun lembaga teknis lainnya, seperti pelayanan keterampilan maupun pengembangan jaringan. (BPKB Jatim, 2001).

\section{SIMPULAN}

1. Lebih dari separuhnya, ibu tidak memberikan ASI eksklusif sampai usia enam bulan secara penuh pada bayinya

2. Terdapat pengaruh yang signifikan pendampingan kader terhadap keberlangsungan pemberian ASI eksklusif, dimana ibu yang tidak mendapat pendampingan kader berisiko hampir tiga kali lebih besar untuk tidak memberikan ASI eksklusif pada bayinya dibandingkan 
dengan ibu yang mendapat pendampingan kader.

Memperhatikan hasil penelitian ini maka direkomendasikan kepada Puskesmas Cikulur untuk memanfaatkan hasil penelitian ini sebagai salah satu bahan masukan dalam menyusun program terkait dengan pengoptimalan peran kader Posyandu dalam peningkatan cakupan ASI eksklusif melalui pendampingan terhadap ibu yang memiliki bayi umur enam bulan ke bawah.

\section{UCAPAN TERIMA KASIH}

Ucapan terima kasih, penulis sampaikan kepada yang terhormat; (1) Direktur Poltekkes Kemkes Banten atas perstetujuan dan dukungan dana yang memungkinkan terlaksananya penelitian ini, (2) Kepala Puskesmas Cikulur, rekan-rekan Bidan Puskesmas Cikulur serta Para kader Posyandu di Wilayah kerja Puskesmas Cikulur yang telah berkontribusi dalam pelaksanaan penelitian ini

\section{DAFTAR PUSTAKA}

Adiningrum, A., 2014. Buku Pintar ASI Eksklusif. Cetakan Pertama. Jakarta : Salsabila.

BPKB Jawa Timur. 2001. Konsep Pendampingan, BPKB Jawa Timur

Notoatmodjo, S., 2010. Metodologi Penelitian Kesehatan. Jakarta : Rineka Cipta.
Notoatmodjo. S., 2010. Promosi Kesehatan Teori \& Aplikasi. Edisi Revisi. Jakarta : Rineka Cipta.

Pusat Data dan Informasi Kesehatan Kemenkes. 2014. Profil Kesehatan : Kementerian Kesehatan.

Saryono. 2011. Metodologi Penelitian Kesehatan. Jogyakarta : Mitra Cendikia.

Soetjiningsih. 1997. ASI : Petunjuk Untuk Tenaga Kesehatan. Cetakan I, Jakarta : Buku Kedokteran EGC

Sitepoe, M., 2013. ASI Eksklusif : Arti Penting Bagi Kesehatan. Cetakan 1. Jakarta Barat : PT Indeks 